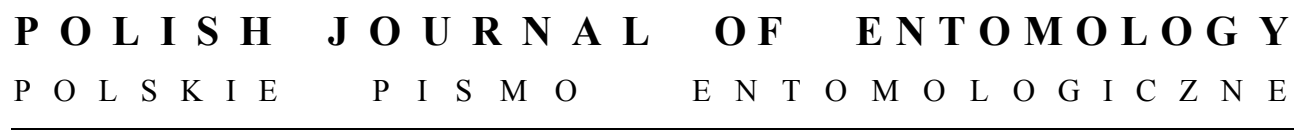

VOL. 82: 343-352

Gdańsk

31 December 2013

DOI: $10.2478 / \mathrm{v} 10200-012-0048-1$

\title{
Palpomyia ryszardi sp. n. from Peru (Diptera: Ceratopogonidae)
}

\author{
GUSTAVO R. SPINELLI \& MARÍA M. RONDEROS
}

División Entomología, Museo de La Plata, Paseo del Bosque s/n, 1900 La Plata, Argentina, e-mails: spinelli@fcnym.unlp.edu.ar; ronderos@fcnym.unlp.edu.ar

\begin{abstract}
A new species of the Palpomyia tibialis group, Palpomyia ryszardi, is described from male and female specimens and from their pupal exuviae from material collected in the vicinities of Iquitos in Peruvian Amazonia. The adult is compared with the most similar Neotropical congener, Palpomyia pseudolacustris SPINELl \& DiPPOLITO, and the pupa with the American species Palpomyia subaspera (COQUILlETT). Descriptions are accompanied by photographs and ink illustrations.
\end{abstract}

KEY WORDS: Diptera, Ceratopogonidae, Palpomyia ryszardi, new species.

\section{INTRODUCTION}

The predaceous midge genus of the tribe Palpomyini, Palpomyia MeIGEN, includes 277 species distributed in all major biogeographic regions of the World except for Antarctica (BORKENT 2013). BORKENT \& SPINELLi (2007) mentioned 46 species from the Neotropical region, and SPINELLI et al. (2009) described four new species from Argentinean and Chilean Patagonia, at the same time transferring P. chilensis INGRAM \& MACFIE to Austrosphaeromias SPINELLI.

The purpose of this paper is to describe, from male and female adults and their pupal exuviae, a new species of the Palpomyia tibialis group from Peruvian Amazonia.

\section{Acknowledgements}

We thank Nélida Caligaris for her technical assistance, Luis Giambelluca for making the map, and Dr Pablo Marino for his critical review of the early version of the manuscript. 


\section{MATERIAL AND METHODS}

Pupae were collected with a pipette and placed in a white tray, having been taken from muddy water at the edge of a shallow pond at Quistococha, in the vicinity of the city

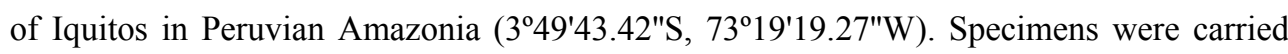
back to the laboratory where they were individually conditioned in vials with a drop of water. Observations were made daily until adult emergence. Adults and pupal exuviae were slide-mounted in Canada balsam following the technique described by WIRTH \& MARSTON (1968). They were examined and measured under a binocular compound microscope, and drawings of certain diagnostic characters were prepared with an attached camera lucida. Photomicrographs were taken with a digital camera (Micrometrics SE Premium) through a Nikon Eclipse E200 microscope. The map was traced from Google Earth and the track was kept in KLM format. Afterwards, the format was converted to .plt using the GPS Visualizer site (http://www.gpsvisualizer.com/gpsbabel/gpsbabel_convert) and also drawn using OziExplorer version 3.95.4. The pupal terminology is based on BORKENT (2012) with the addition of the following abbreviations of measurements: DAL dorsal apotome length and DAW - dorsal apotome width, and on the Manual of Central American Diptera (BROwN et al. 2009) for adults. The type of our new species is deposited in the entomological collection at the Museo de La Plata, Argentina (MLP).

\section{RESULTS}

\section{Palpomyia ryszardi sp. $\mathrm{n}$.}

(Figs 1-24)

\section{Diagnosis}

The only Neotropical Palpomyia in the tibialis group with the following combination of characters: male dark brown; fore femur with 1-2 ventral spines, mid and hind femora unarmed; gonostylus short, with ventromesal cluster of short, black spines; distal portion of parameres divided, each stem with bulbous tip, then recurved in a slender anterolaterally directed process; basal arms of aedeagus deeply curved, elongated, slender and directed laterally. Female with fore and hind femora spinose; scutum yellow with dark brown anteromesal spot and two separate dark brown spots on prescutellar area; legs mainly yellow. Pupa with dorsal apotome rounded; respiratory organ 6.63 times longer than broad; ventral surface of anterior $1 / 3$ of female abdominal segment 9 with a pair of admedian, small and rounded bare areas.

\section{Description of adults}

Male. Head (Fig. 1) dark brown. Eyes widely separated, by diameter of 5-6 ommatidia. Antenna with plume moderately dense, not extending beyond flagellomere 11, 
flagellomeres brown except for pale narrow bases, flagellomeres 2-10 short, 11-13 subcylindrical, elongate; antennal ratio (11-13/1-10) 1.23. Clypeus with 21 setae. Palpus brown, segment 3 with 3-4 mesal sensilla on inner margin; palpal ratio 2.20 .

Thorax. Uniformly dark brown. Scutum without anterior tubercle, pilose, with 3 large prealar setae; scutellum pilose, with 4 large setae. Legs dark brown, fore leg paler, mid and hind femora paler at narrow bases; fore femur slender, with 1-2 ventral spines, mid, hind femora unarmed; tarsi pale brown; tarsomere 5 in all legs without ventrolateral bristle-like setae; claws small, equal-sized in all legs, curved, each with basal inner tooth. Wing (Fig. 2) membrane infuscated, veins dark brown; $2^{\text {nd }}$ radial cell $1.75-2.15(1.95, \mathrm{n}=2)$ times longer than $1^{\text {st; }}$, wing length $1.31-1.35(1.33, \mathrm{n}=2) \mathrm{mm}$, width $0.43-0.45(0.44, \mathrm{n}=2) \mathrm{mm}$; costal ratio $0.80(\mathrm{n}=2)$. Haltere brown.
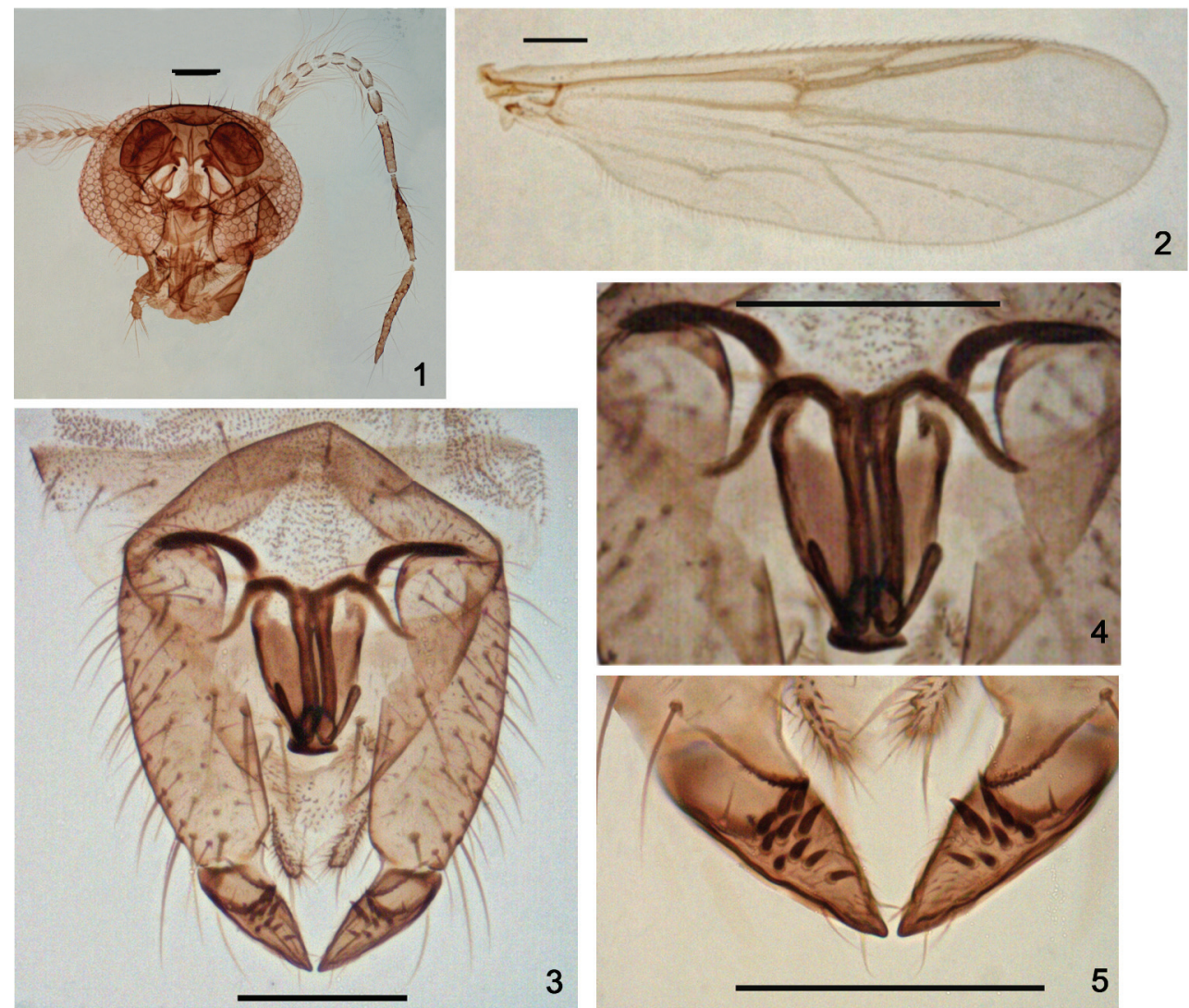

3

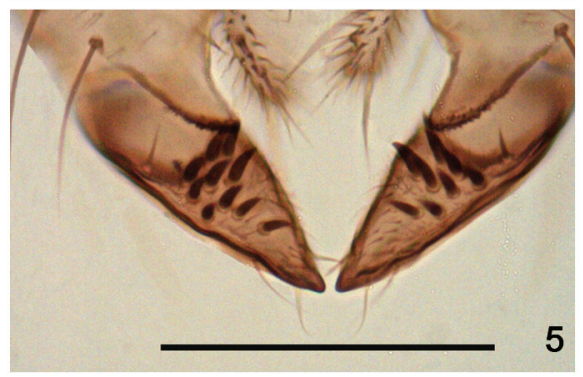

Figs 1-5. Male of Palpomyia ryszardi SpInELli \& Ronderos: 1 - head, 2 - wing, 3 - genitalia, $4-$ detail of parameres and aedeagus, $5-$ detail of gonostylus. Scale bars $=0.05 \mathrm{~mm}$. 
Abdomen. Dark brown. Genitalia as in Figs 3-5. Tergite 9 tapering distally to rounded apex, cercus slender, elongate, with apical large seta; sternite 93.5 times broader than long, base greatly curved with deep caudomedian excavation. Gonocoxite straight, three times longer than broad, extending to base of cerci, with slender ventroapical lobe finely toothed on ectal margin (Fig. 5); gonostylus short, tapering distally to pointed tip, with ventromesal cluster of 8-10 short, black spines. Parameres narrow fused anteriorly, heavily sclerotized; apodemes slender, distal portion divided, each with bulbous tip, then recurved in slender anterolaterally directed process with blunt tip. Aedeagus heavily sclerotized, stout; basal arms slender, elongated, deeply curved, directed laterally; basal arch 0.4 of total length, main body gently tapering distally with arrowhead-shaped tip.
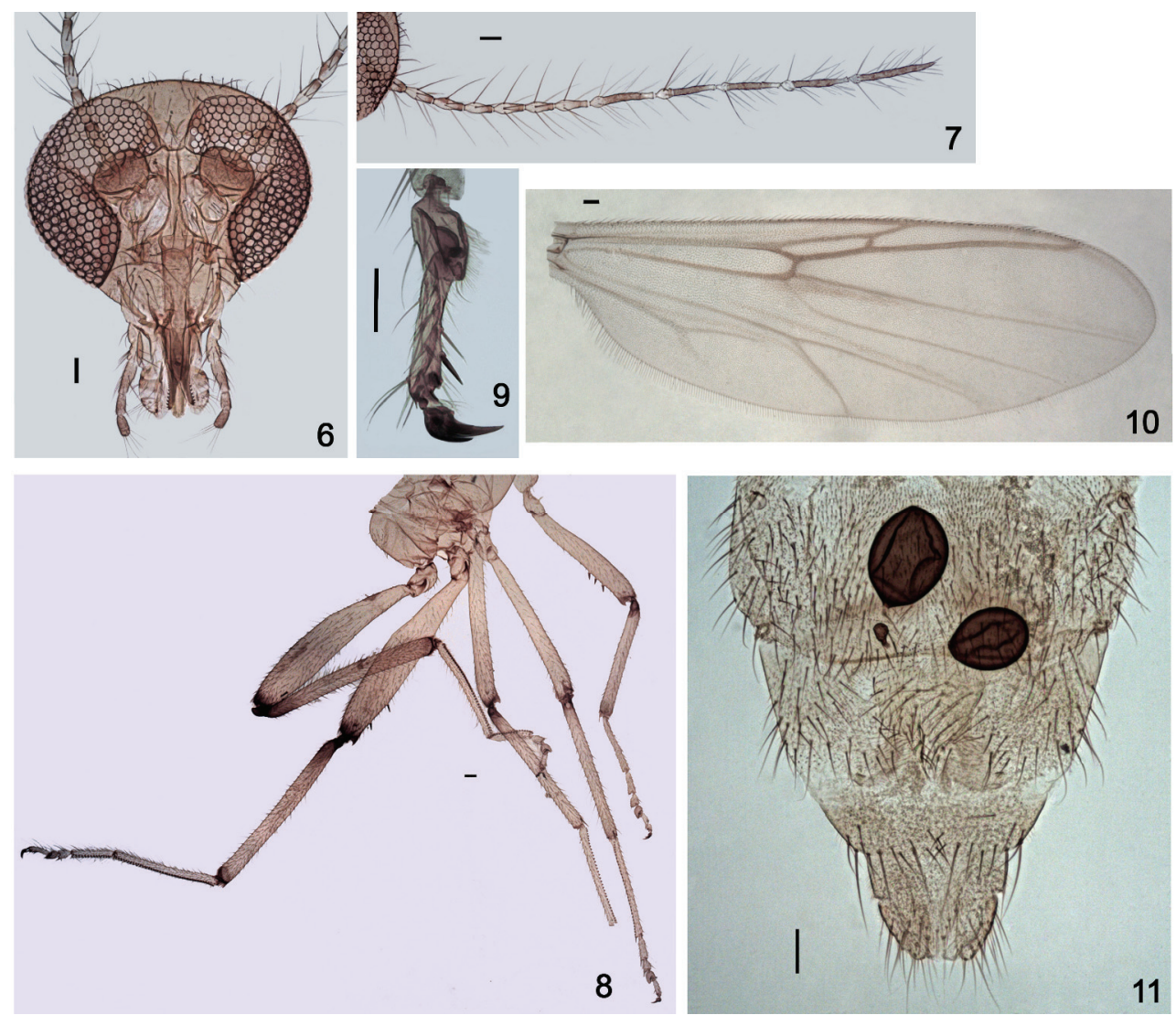

Figs 6-11. Female of Palpomyia ryszardi SpINELLi \& Ronderos: 6 - head, 7 - flagellum, 8 - legs, 9 - tarsomere 5 of hind leg, 10 - wing, 11 - tip of abdomen showing spermathecae. Scale bars $=0.05 \mathrm{~mm}$. 
Female. Head (Fig. 6) yellowish. Eyes separated by diameter of 2-3 ommatidia. Antenna (Fig. 7) with flagellomeres 2-8 bottle-shaped, pale at basal 2/3, apical 1/3 dark brown, flagellomeres 9-13 greatly elongated, dark brown except for pale narrow bases; antennal ratio 1.40-1.48 (1.44, $\mathrm{n}=2)$. Clypeus with 32-34 setae. Palpus yellowish brown, segment 3 with 3-4 mesal sensilla on inner margin; palpal ratio $2.80(n=2)$. Mandible heavily sclerotized; inner margin with 11-12 $(\mathrm{n}=2)$ stout, sharply pointed teeth.

Thorax. Yellow. Scutum without anterior tubercle, densely pilose, with dark brown anteromesal spot and two separate dark brown spots on prescutellar area; 4 large prealar setae; scutellum pilose, darker at sides, with 4 large setae. Legs (Fig. 8) yellow, knees darkish, extreme base and narrow apex of hind tibia dark brown; fore femur slender, armed with 3-4 ventral spines, mid femur unarmed, hind femur armed with 1-2 ventral spines; tarsi uniformly yellow; tarsomere 5 in all legs with pair of ventrolateral bristle-like setae (Fig. 9); claws small, equal-sized in all legs, curved, all with conspicuous basal inner teeth. Wing (Fig. 10) membrane infuscated, veins dark brown; $2^{\text {nd }}$ radial cell 2.12-2.60 (2.36, $\mathrm{n}=2)$ times longer than $1^{\text {st }}$, vein $\mathrm{M}_{3}$ nearly straight; wing length $2.50-2.66(2.58, \mathrm{n}=2) \mathrm{mm}$, width 0.85-0.97 (0.91, $\mathrm{n}=2) \mathrm{mm}$; costal ratio 0.87-0.89 $(0.88, \mathrm{n}=2)$. Haltere brown.

Abdomen (Fig. 11). Brownish except for dark brown segment 1, pilose, without tergal apodemes. Sternite 8 with abundant, strong pilosity mesally; anterior margin with $\mathrm{V}$-shaped excavation that is $1 / 3$ of total length; posterior margin roundly excavated; sternite 9 moderately sclerotized, divided into pair of very slender, pointed, hook-like arms. Sternite 10 shield-shaped, with 6 pairs of setae. Two heavily sclerotized, large spermathecae, unequal-sized, ovoid with short, narrow necks, measuring 132 by $100 \mu \mathrm{m}$, and 102 by $83 \mu \mathrm{m}$; plus rudimentary third spermatheca.

\section{Description of pupa}

Female (Figs 12-17, 21-23). Total length 4.47-5.05 (4.76, $\mathrm{n}=2$ ) mm. General colouration brown. Dorsal apotome (Fig. 13) with disc 1.84 times wider than long, disc surface covered with rounded strong tubercles; anterior margin rounded, with strong rounded tubercles; posterior margin free of tubercles, slightly concave, each side of posteromesal portion with raised area bearing 2 dorsal apotome sensilla (Fig. 13), as follows: DA-1-H medium-sized, thin, located on well-developed tubercle, DA-2-H pore at tubercle base; DAL $0.18 \mathrm{~mm}$, DAW $0.264 \mathrm{~mm}$, DAW/DAL 1.46. Cephalothorax (Fig. 12) rectangular, dark brown, surface covered with small spinules, with short, poorly developed medial crest, antenna elongate, apex extending posteriorly to various points along anterior margin of wing, mouthparts short, restricted to area anterior to forecoxae/trochanters; apex of labrum truncated, mandible present (Fig. 21); length 1.62$1.74(1.68, \mathrm{n}=2) \mathrm{mm}$, width 1.20-1.44 (1.32, $\mathrm{n}=2) \mathrm{mm}$. Cephalothoracic sensilla (Figs 1416) as follows: 2 dorsolateral cephalic sclerite sensilla (Fig. 15): DL-1-H- DL-2-H without seta on flattened tubercle; 2 anterolateral sensilla on single tubercle (Fig. 15): AL-1-T 
medium-sized, thin seta, AL-2-T pore on slightly rounded tubercle; anteromedial sensillum (AM-1-T) pore (Fig. 14); 5 dorsals present (Fig. 16): D-1-T-D-2-T, D-5-T long, thin setae, D-4-T, medium-sized, D-3-T pore, supraalar 2 present. Respiratory organ (Figs 12,14) brown, tubular, surface bare, 6.63 times longer than broad, with 10-12 apical pores; RO length $0.288-0.324(0.306, \mathrm{n}=2) \mathrm{mm}$, RO width $0.048-0.072(0.06, \mathrm{n}=2) \mathrm{mm}$; pedicel (Fig. 14) smooth, short, length $0.024(\mathrm{n}=2) \mathrm{mm}, \mathrm{P} / \mathrm{RO} 0.0785$. Two clypeal/labrals (Fig. 21), CL-1-H-CL-2-H medium-sized, thin sensilla; two oculars sensilla (Fig. 21): O-2$\mathrm{H}$ pore, O-3-H campaniform sensillum. Abdominal segments pale brown, surface smooth at mesal portion, with band of small pointed spinules on anterior and posterior margins. First abdominal segment (Fig. 22) with setae as follows: D-2-I-D-3-I medium-sized setae on rounded, small tubercle, D-7-I pore, 3 setae on posteromesal portion, D-4-I pore, D-8-I peg, D-9-I long, thin seta; 3 lateral setae: L-1-I medium-sized, thin seta, L-2-I short, thin seta, L-3-I minute seta, all setae on small tubercles. Fourth abdominal segment with sensillar pattern (Fig. 23) as follows: D-1-IV absent, D-2-IV-D-3-IV on rounded small tubercle, sensilla not visible, D-4-IV pore, D-5-IV minute seta, D-7-IV- D-8-IV small, thin setae, both on stout tubercle, D-9-IV medium-sized, thin seta on stout tubercle; L-1-IV short, stout seta, on small rounded tubercle, L-2-IV and L-4-IV on stout, blunt tubercles, without seta, L-3-IV short, thin seta, located on apical, triangular, pointed tubercle; 3 ventral setae, V-5-IV very short, stout seta, V-6-IV rounded small tubercle without seta, V-7-IV thin, small seta located on flattened tubercle. Segment 9 (Fig. 17) length 0.360$0.396(0.378, \mathrm{n}=2) \mathrm{mm}$, width $0.288-0.336(0.312, \mathrm{n}=2) \mathrm{mm}$; ventral surface with pointed, posteriorly directed spinules on anterior $1 / 3$ except for two small, rounded, admedian bare areas; terminal process short, moderately divergent, ventral surface with scattered minute spinules, pore on ectal margin, tip dark; length 0.144-0.192 $(0.168 \mathrm{n}=2) \mathrm{mm}$, basal width $0.096(\mathrm{n}=2) \mathrm{mm}$.

Male (Figs 18-19). Similar to female with usual sexual differences. Total length 3.513.61 (3.56, n=2) mm. Exuviae pale brown. Dorsal apotome $1.57 \mathrm{x}$ wider than long (Fig. 18), anterior margin with large tubercles, tapering to pointed tip, posterior margin free of tubercles, concave; DAL $0.168(\mathrm{n}=2) \mathrm{mm}$, DAW 0.204-0.240 (0.22, $\mathrm{n}=2) \mathrm{mm}$, DAW/DAL 1.214-1.428 (1.321, $n=2)$. Respiratory organ length $0.252(n=2) \mathrm{mm}$, width $0.06(\mathrm{n}=2) \mathrm{mm}$; pedicel length $0.024(\mathrm{n}=2) \mathrm{mm}, \mathrm{P} / \mathrm{RO} 0.095(\mathrm{n}=2)$. Cephalothorax length 1.20-1.23 (1.215, n=2) mm, width 0.93-0.99 (0.96, $\mathrm{n}=2) \mathrm{mm}$. Segment 9 (Fig. 19) with dorsal and ventral surfaces bearing posteriorly directed, small spicules, ventral genital lobe short, globose, surface wrinkled, length 0.288-0.312 $(0.3, \mathrm{n}=2) \mathrm{mm}$, width $0.276(\mathrm{n}=2) \mathrm{mm}$, terminal process length $0.096-0.132(0.114, \mathrm{n}=2) \mathrm{mm}$, width $0.06-0.084(0.072, \mathrm{n}=2) \mathrm{mm}$, extreme apex sharply pointed, darkish.

\section{Distribution}

Peru. Known only from the type-locality (Fig. 24). 

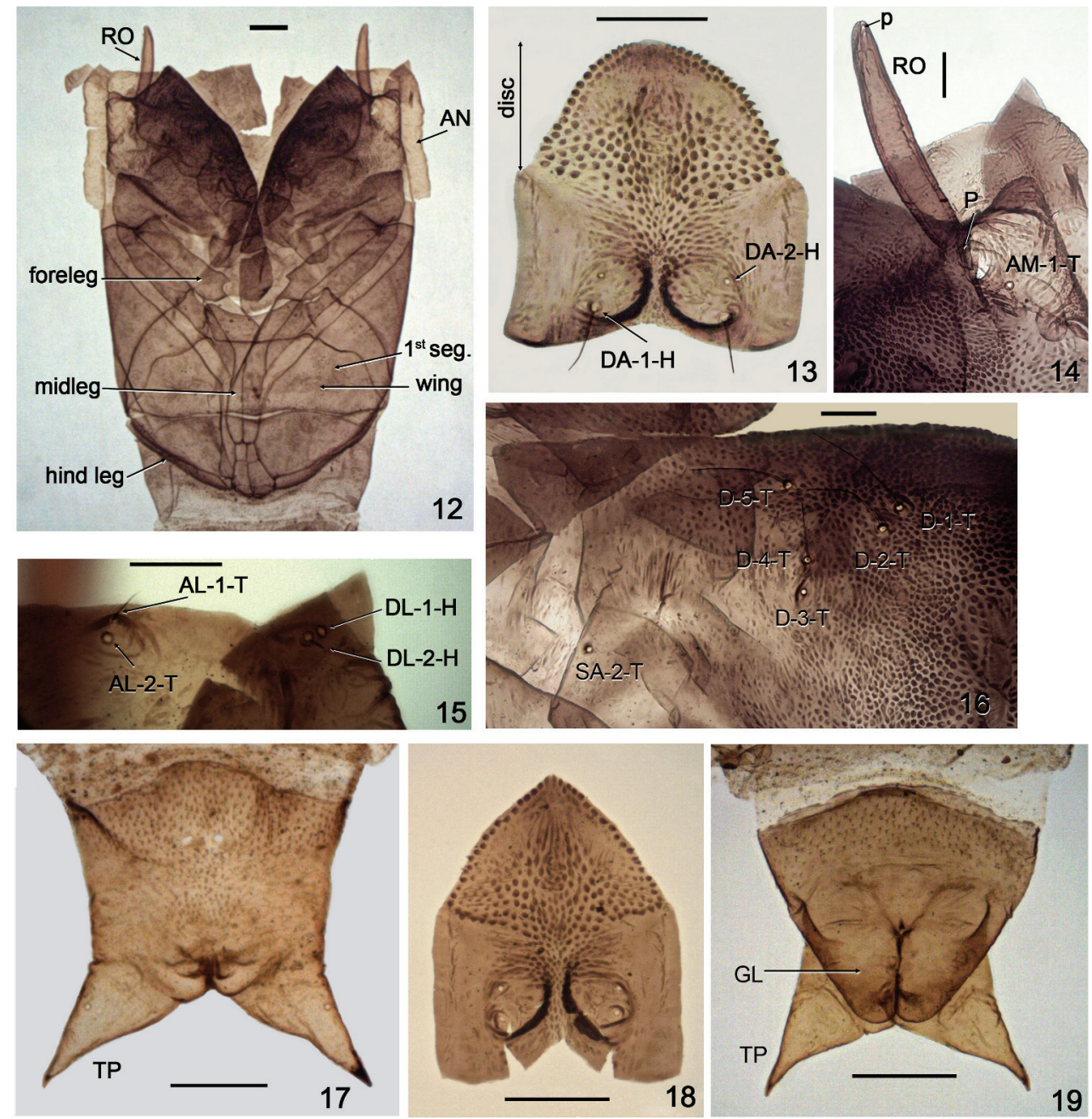

Figs 12-19. Pupa of Palpomyia ryszardi Spineldi \& Ronderos: 12-17 - female, 18-19 - male. 12 - detail of cephalothorax (ventral view), 13 - dorsal apotome, 14 - respiratory organ, 15 - anterolateral sensillum and dorsolateral cephalic sclerite sensillum, 16 - dorsal setae, 17 - segment 9, 18 - dorsal apotome, 19 - segment 9. Scale bars $=0.05 \mathrm{~mm}$.

AN - antenna, AL - anterolateral sensillum, AM - anteromedial sensilla, D - dorsals, DA - dorsal apotome sensilla, DL - dorsolateral cephalic sclerite sensillum, GL - genital lobe, P - pedicel, $\mathrm{RO}$ - respiratory organ, $\mathrm{SA}$ - supraalar, $\mathrm{TP}$ - terminal processes.

\section{Type material}

Holotype male with pupal exuviae, labelled "Perú, Iquitos, Quistococha, 13-VIII-1996, G. Spinelli” (MLP). Paratypes, 1 male, 2 females, same data as holotype. 


\section{Derivation of specific epithet}

We are pleased to name this new species after our esteemed colleague, Ryszard Szadziewski, in recognition of his remarkable contributions to the systematic studies of extant and fossil biting midges.
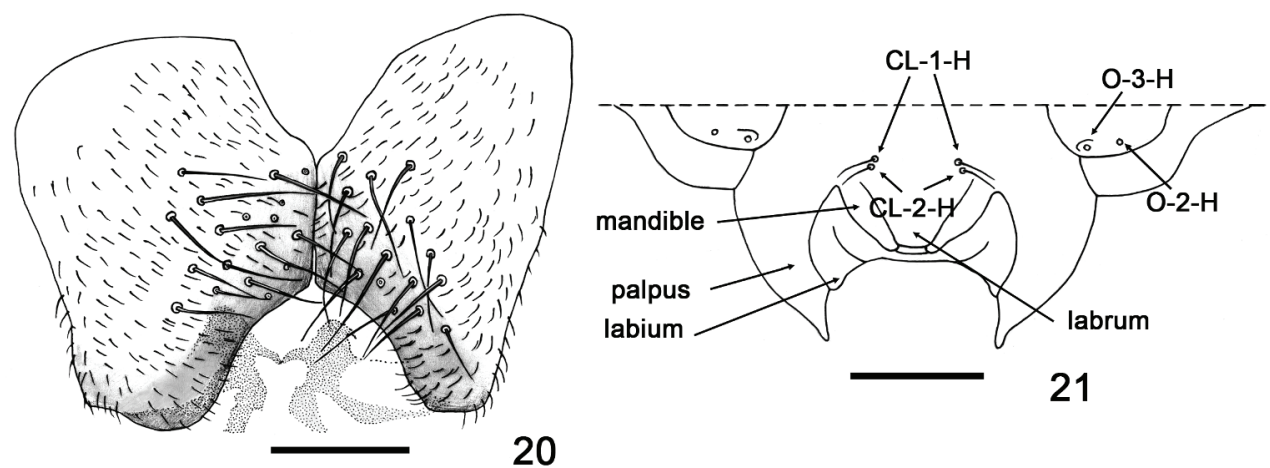

20

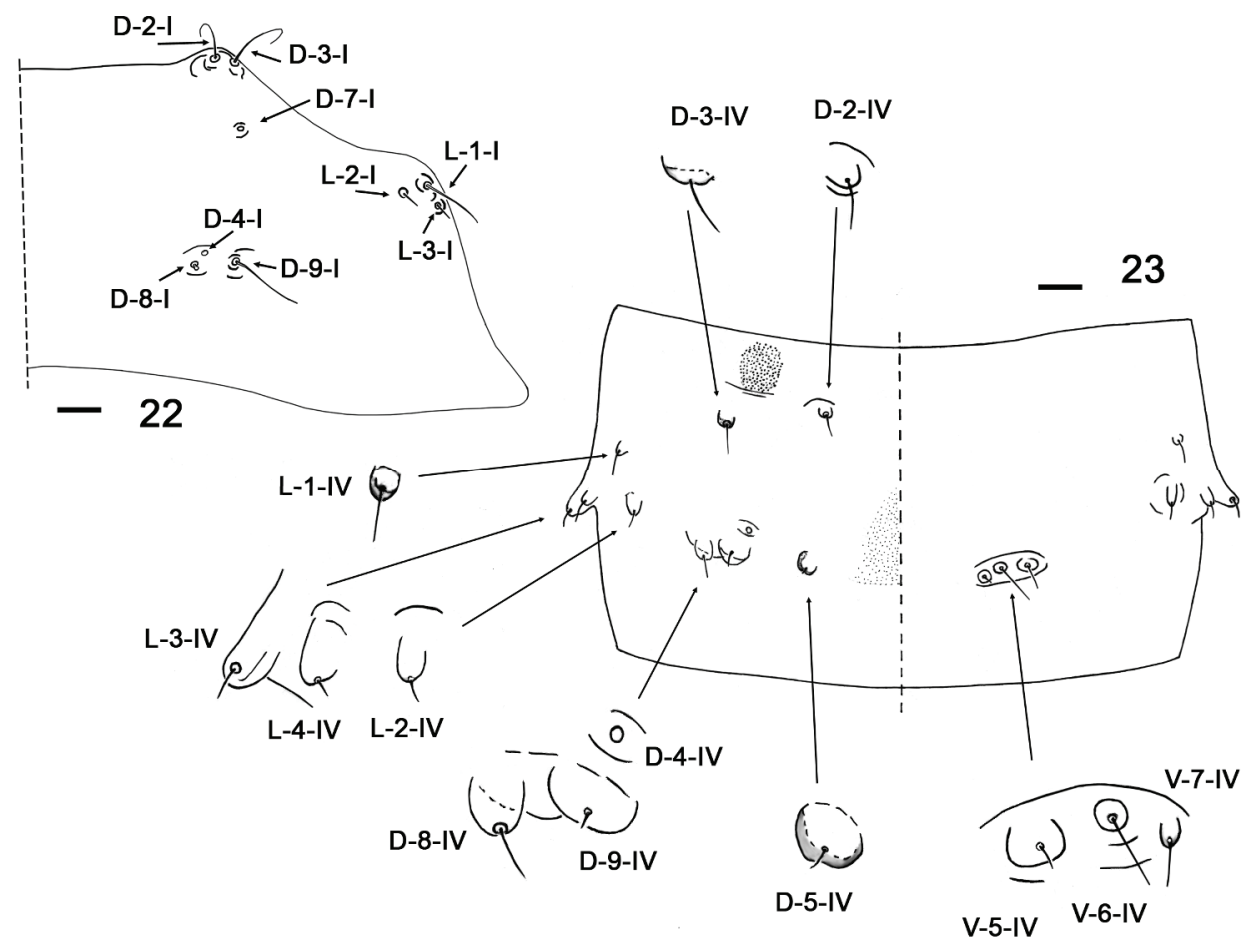

Figs 20-23. Female of Palpomyia ryszardi Spinelli \& Ronderos: 20 - adult, 21-23 - pupa. 20 - sternites 8-9, 21 - clypeal/labral sensilla (CL) and ocular sensillum (O), details of mouthparts, 22 - first abdominal segment (dorsal view), 23 - fourth abdominal segment (dorsal and ventral view) with details of setae and tubercles. Scale bars $=0.05 \mathrm{~mm}$. 


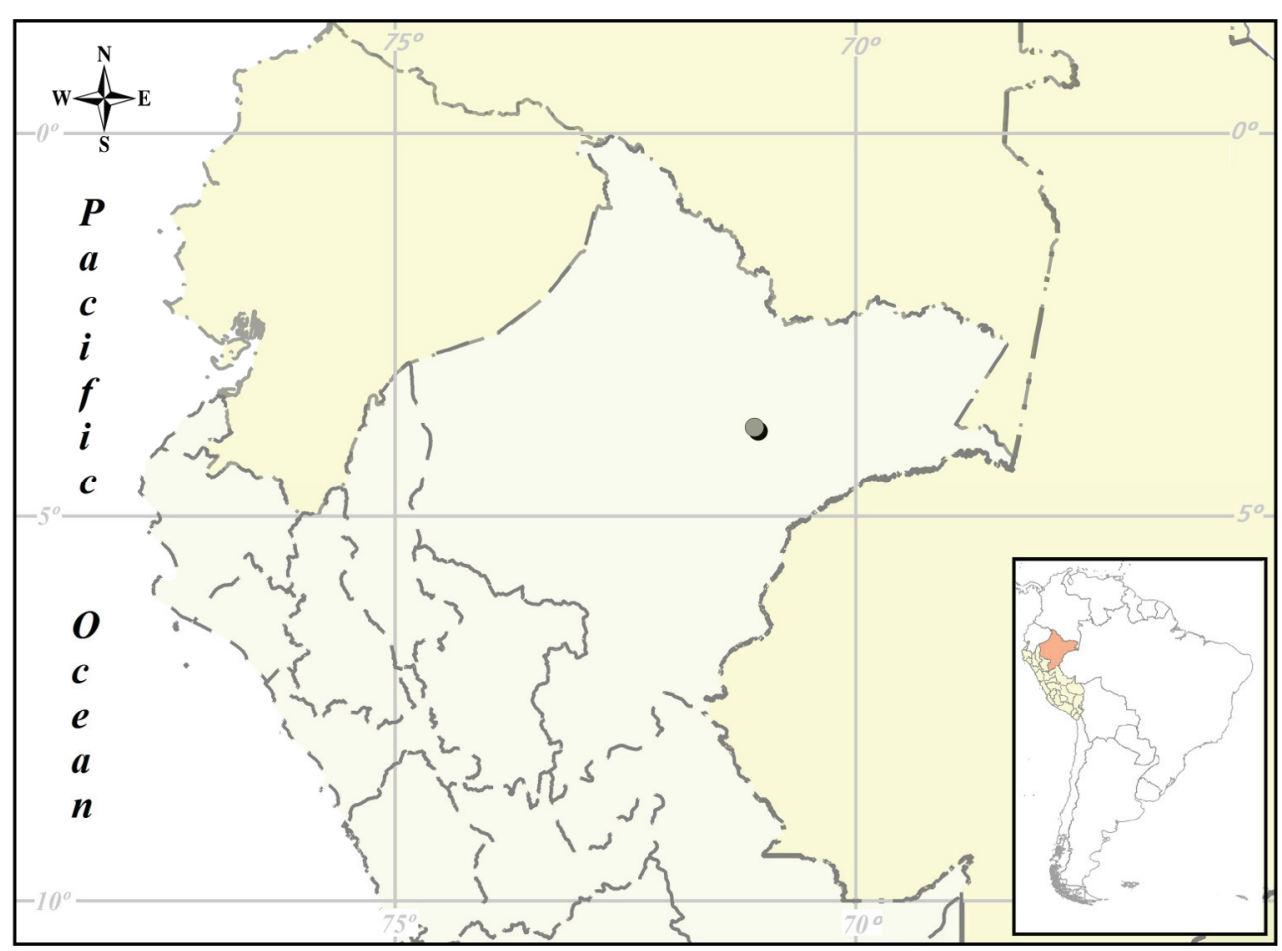

Fig. 24. Distribution map of Palpomyia ryszardi SPINELLI \& RONDEROS.

\section{DISCUSSION}

This new species new belongs to the Palpomyia tibialis group, as defined by GROGAN \& WIRTH (1979) with modifications by SPINELLI et al. (2009).

The adults of $P$. ryszardi are most similar to $P$. pseudolacustris DipPOLITO \& SPINELLI from Rondonia, in Brazilian Amazonia, especially in the general features of the male genitalia, such as the presence of a slender lobe in the ventroapical margin of the gonocoxite, the very short gonostylus with a ventromesal cluster of black spines, and the parameres divided distally, each one with a bulbous tip and recurved in a slender anterolaterally directed process with blunt tip. However, both sexes of P. pseudolacustris are distinctly dark brown, including the scutum, legs and abdomen. The female mid femur is armed with 3 ventral spines, the female abdomen has 2 pairs of tergal apodemes, the aedeagus has shortly recurved basal arms and higher basal arch, and the ectal margin of the gonocoxite ventroapical lobe is smooth, not toothed. The Nearctic species $P$. weemsi GROGAN \& WIRTH also exhibits a similar sexual dimorphism with regard to the leg colouration and similar male genitalia, but the female scutum is dark brown; the gonocoxite 
is distinctly shorter, bears a large basal hump and a small ventrodistal tubercle covered with fine setae instead of the ventroapical lobe finely toothed on the ectal margin.

The pupa of this new species is similar to the American species P. subaspera (COQuilletT), which was described by Grogan \& WirTh (1979). It is one of the two species of the Palpomyia tibialis group that inhabits the Neotropics of which the pupa is known. During the present study we compared the pupa of $P$. ryszardi with specimens of $P$. subaspera from Patagonia housed in the Museo de La Plata. The pupa of $P$. subaspera differs from $P$. ryszardi by the pointed anterior margin of the dorsal apotome, by the respiratory organ 3 times longer than broad, by the bare areas on the anterior $1 / 3$ of the ventral surface of the female segment 9 which are longitudinally aligned, hourglassshaped, and by the male segment 9 with elongate genital lobe.

\section{REFERENCES}

Borkent A. 2012. The pupae of the families of Culicomorpha - morphology and a new phylogenetic tree. Monograph. Zootaxa 3396: 1-98.

Borkent A. 2013. World species of biting midges (Diptera: Ceratopogonidae). On line http://www.inhs.uiuc.edu/research/FLYTREE/CeratopogonidaeCatalog.pdf, 236 pp. Last update February 20, 2013.

Borkent A., Spinelli G.R. 2007. Neotropical Ceratopogonidae (Diptera: Insecta). [In:] AdIS J., Arias J.R., Rueda-Delgado G., WNATZEn K.M. (eds). Aquatic biodiversity in Latin America (ABLA). Vol. 4, Pensoft, Sofia-Moscow, 198 pp.

Brown B.V., Borkent A., Cumming J.M., Wood D.M., Woodley N.E., Zumbado M.A. 2009. Manual of Central American Diptera. Vol. 1. NRC Research Press, Ottawa, Ontario, Canada, $714 \mathrm{pp}$.

Grogan W.L. JR., WiRTH W.W. 1979. The North American predaceous midges of the genus Palpomyia MeIGEN (Diptera: Ceratopogonidae). Memoirs of the Entomological Society of Washington 8: 1-125.

Spinelli G.R., Grogan W.L. JR., Ronderos M.M. 2009. A revision of the Patagonian predaceous midges of the genus Palpomyia MeIGEN (Diptera: Ceratopogonidae). Insect Systematics and Evolution 40: 43-70.

Wirth W.W., MARSTON N. 1968. A method for mounting small insects on microscope slides in Canada balsam. Annals of the Entomological Society of America 61: 783-784.

Received: 14 October 2013

Accepted: 22 October 2013 